\title{
The Chicken and Egg Question: Satisfaction with Democracy and Voter Turnout
}

Filip Kostelka, University of Montreal

André Blais, University of Montreal

ABSTRACT Political scientists, analysts and journalists alike have long believed that the degree of satisfaction with the functioning of democracy determines voter turnout. We use survey data from 24 panel studies to demonstrate that this causal relationship is actually reversed: voter turnout affects satisfaction with democracy. We also show that this reversed relationship is conditioned by election type, electoral system, and election outcomes. These findings are important because: (1) They question conventional wisdom and a large body of scientific literature; (2) They invite a more nuanced approach towards the study of the relationship between evaluations of regime performance and political participation; and (3) They emphasize the vital role of elections in shaping citizens' perception of the democratic process.

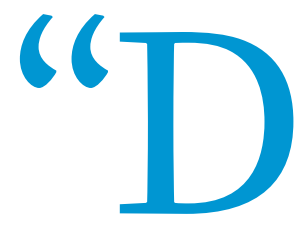

oes a low election turnout indicate voters are disillusioned or content?" asked a headline in one of the world's oldest newspapers, The Herald, during the run-up to the 2003 Scottish Parliamentary election (The Herald 2003). The Glasgow-based broadsheet speculated that some eligible voters abstain in order to "register their disillusion," while others are "content with the way things are." This intuition reflects the current state of the scientific debate on the impact of citizen's satisfaction on voter turnout. More broadly, the headline itself shows how pundits usually conceptualize the relationship between satisfaction with the way democracy works and voter turnout: the former as the cause and the latter as the effect. However, such a view is incomplete. There are both theoretical reasons and empirical findings that suggest the presence of a reversed relationship. In this article, we use data from 24 panel studies and debunk the conventional wisdom. We find no evidence for the effect of democratic satisfaction on voter turnout, but robust support for the

Filip Kostelka is postdoctoral fellow at the Institutions and Political Economy Research Group, University of Barcelona, Spain and associate researcher at the Centre d'études européennes, Sciences Po, Paris, France. When conducting this research, he worked as postdoctoral fellow at the Research Chair in Electoral Studies, University of Montreal, Canada, and coordinated the Making Electoral Democracy Work project (http:// electoraldemocracy.com). He can be reached at filip.kostelka@sciencespo.fr.

André Blais is professor in the Department of Political Science and holds a Research Chair in Electoral Studies at the University of Montreal, Canada. He leads the Making Electoral Democracy Work project (http://electoraldemocracy.com) and can be reached at andre.blais@umontreal.ca. reversed relationship. In other words, voter turnout tends to affect satisfaction and not the other way around. In national and subnational elections, the effect is positive. It is stronger in majoritarian electoral systems and among voters who think that their preferred party won the election. Conversely, in supranational elections, the effect is negative and affects the whole electorate.

\section{HYPOTHESES}

Satisfaction with democracy is best understood as an indicator of regime performance, falling between more diffuse support for political community and regime principles and more specific support for regime institutions and political actors (Norris 1999; Linde and Ekman 2003; Norris 2011; Linde 2012). Political science literature that examines the impact of this satisfaction on voter turnout is divided into two camps (Pacek, Pop-Eleches, and Tucker 2009; Ezrow and Xesonakis 2016). Some literature, especially earlier work, perceives nonvoting as a sign of satisfaction with the current state of affairs (e.g., Tingsten [1937] 1963; Wilson 1936; Lipset 1981). Other work, especially more recent literature, holds that "dissatisfaction with democratic performance is usually regarded, at least implicitly, as an important cause of civic disengagement" (Norris 2011; see also Kostadinova 2003). Both perspectives agree on the direction of causality and assume that perception of the overall functioning of the political system motivates the decision to vote or abstain. Based on this assumption, political scientists frequently use satisfaction with democracy to predict voter turnout (e.g., Grönlund and Setälä 2007; Flickinger and Studlar 2007; Hadjar and Beck 2010; Karp and Milazzo 2015). 
Hypothesis 1a: Satisfaction with democracy decreases voter turnout.

Hypothesis 1b: Satisfaction with democracy increases voter turnout.

Most empirical research either employs post-election surveys or studies macro-level data using measurements from nonelectoral surveys. Both methods are problematic. The macro-level data approach can provide only indirect evidence of the causal mechanism, while the post-election type of measurement implicitly presupposes that the election itself has not altered citizens' level of democratic satisfaction. Such presupposition is questionable.

Elections are at the heart of contemporary democracy (Dahl 1971; Huntington 1991). They are the principal means of changing the political course of a democratic polity. It is through elections that an unpopular incumbent can be voted out of office and replaced by a more popular alternative. They represent the most tangible embodiment of the democratic principle to which citizens are regularly and systematically exposed. It would be surprising if elections had no effect on citizens' views about how democracy works in their country. We hypothesize that, in most circumstances, elections boost satisfaction with democracy, especially among citizens who play the democratic game.

Hypothesis 2: Electoral participation increases satisfaction with democracy.

However, the impact of electoral participation is likely to vary across contexts and individuals. An increase in satisfaction can be expected only if there is a clear link between election outcomes and government composition. A quintessential example of elections where such a link is tenuous are supranational elections to the European Parliament (EP). Although they are run essentially as national contests on national issues (Reif and Schmitt 1980), a party winning the national vote may end up in the losing camp at the supranational level. Furthermore, the European Union's institutional structure and operating mechanisms further hinder accountability (Follesdal and Hix 2006). Consequently, the positive effect of elections on satisfaction should be weak or inexistent in EP elections. On a more general level, following Aarts and Thomassen (2008), we expect that elections under majoritarian electoral rules allow for more accountability and, therefore, boost in satisfaction. Winners-those who prefer the party (or parties) that won the election-are likely to see their satisfaction increase much more than those who prefer a losing party.

Hypothesis 5: Satisfaction with democracy increases the most among election winners.

The impact of elections and election outcomes on mass political attitudes has been studied empirically by a vibrant body of political science literature. These studies have generally found that those who participate in an election consider the outcome of the election as more legitimate than do abstainers (Nadeau and Blais 1993) and that winners become more satisfied than losers (Anderson et al. 2005; Henderson 2008; Singh 2014; Campbell 2015; Singh and Thornton 2016). Although these studies provide valuable insights, they suffer from the same limitation as the aforementioned research because they are based on the same kind of post-electoral surveys. They consequently do not allow researchers to control for pre-election attitudes. Panel studies, which do allow such a control, are rare, usually cover only a single election, and often study different, typically more specific, types of political support. These studies have found that voting in elections increases external efficacy (Ginsberg and Weissberg 1978) and perceptions of legislators' responsiveness (Clarke and Kornberg 1992). Those increases tend to be the strongest among election winners, who also become more trustful of government (Anderson and LoTempio 2002) and less cynical about political parties (Banducci and Karp 2003). Increases in satisfaction with democracy were observed in the 1999 legislative election in New Zealand (Banducci and Karp 2003), the 2010 North RhineWestphalia election (Singh, Karakoç, and Blais 2012), and the French presidential election of 2012 (Beaudonnet et al. 2014). Blais and Gélineau (2007) found a positive effect on voters in general and winners, particularly in the Canadian election of 1997. Finally, Blais, Morin-Chassé, and Singh (2015) found that satisfaction increased among those who voted for parties that gained greater shares of votes, seats, and cabinet portfolios. All these findings reveal that the use of post-electoral measures of satisfaction can be a risky strategy since causality may go in the opposite direction. We thus proceed to a systematic examination of the relationship between satisfaction with democracy and voter turnout.

\section{All these findings reveal that the use of post-electoral measures of satisfaction can be a risky strategy since causality may go in the opposite direction.}

satisfaction with democracy more strongly than elections using proportional representation. ${ }^{1}$

Hypothesis 3: The positive effect of electoral participation on satisfaction with democracy is weak or inexistent in European Parliament elections.

Hypothesis 4: The positive effect of electoral participation on satisfaction is stronger in majoritarian electoral systems.

As for individual-level variations, it is obvious that election outcomes are not equally liked or disliked by all voters. Citizens' preferences presumably condition election-related change

\section{DATA}

To test the five hypotheses, we use individual-level survey data from the Making Electoral Democracy Work project (Blais 2010; Stephenson et al. 2017). The project studies national, subnational, and supranational elections held between 2010 and 2015 in five countries (Canada, France, Germany, Spain, and Switzerland). ${ }^{2}$ Our dataset consists of 24 regional election samples that cover 17 elections held between 2010 and 2015 (five national, nine subnational and three supranational; see the online appendix). These data are particularly suitable for disentangling the satisfactionturnout nexus since it has a two-wave panel structure and provides both a pre-election and post-election measure of satisfaction 
with democracy. Respondents were asked, generally one week before and one week after the given election, to indicate their degree of satisfaction with democracy at the election-related level of governance. They were proposed a o-10 scale where o means "not satisfied at all" and 10 "very satisfied." 3 We divide the scale by ten so that it varies between $o$ and 1 .

The control variables are the classic predictors of electoral participation commonly used in political science research such as age, education, and political interest (Blais 2007, see the online appendix for descriptive statistics). It should be noted that all the control variables were measured in the pre-election surveys while the main variable of interest-reported electoral participation-was measured after the election. Hypotheses 3 and 4 are tested by dummy variables that distinguish between types of elections (national, subnational and supranational) and different electoral systems (majoritarian and proportional). To test hypothesis 5 , we introduce two dummy variables that ascertain whether voters think the party for which they had cast a vote won or lost (abstainers and don't knows are the reference category).4 Finally, all of the following analyses include region (or election-region) dummies.

\section{FINDINGS}

In table 1 , we present the results of four analyses. Model 1 regresses electoral participation on the pre-election and post-election measures of satisfaction with democracy alone. 5 In conformity with hypothesis 2, the post-election measure is much more strongly associated with voting than the pre-election one. Because preelection measures are also positive and statistically significant, however, we cannot yet rule out that pre-election satisfaction fosters voting too (hypothesis $1 \mathrm{~b}$ ). Therefore, in model 2, we test the pre-election measure alone while incorporating the control variables. The coefficient is now even smaller than in model 1 and no longer meets the most lenient threshold of statistical significance. This means that the weak positive effect of the pre-election measure in model 1 was actually driven by variables more closely related to voter turnout, such as education or interest in politics. People who are dissatisfied with democracy before the election do not participate less because they are dissatisfied but because they are less educated or uninterested in politics. In contrast, the effect of the post-election measurement in model 3 , which also incorporates control variables, is still substantial and meets the most rigorous threshold of statistical significance. Furthermore, the findings from models 2 and 3 are confirmed in model 4 in which the two measures are tested jointly with the control variables. While the post-election measure remains statistically significant, the pre-election measure changes sign and is insignificant. All the models point in the same direction: conventional hypotheses ( $1 \mathrm{a}$ and $1 \mathrm{~b}$ ) are rejected while the first alternative hypothesis (2) is supported.

Figure 1 graphically expresses the relationship between electoral participation and post-election satisfaction. It displays the average marginal effects (AME) calculated from model 3 . If post-election satisfaction was the cause and voting the effect, it could be understood as the change in the probability of voting when respondents' value on satisfaction increases. If we did not have the pre-election measure, we would conclude that a shift from no satisfaction to maximal satisfaction increases the probability of voting by approximately five percentage points. This is a large effect, which would appear to provide compelling evidence for the conventional interpretation (hypothesis 1b). Comparing preelectoral and post-electoral satisfaction, however, demonstrates that turnout is related to post-election satisfaction and not to pre-election satisfaction. It is thus voting that boosts satisfaction and not the other way around.

The impact of voter turnout on satisfaction with democracy is formally tested in table 2. The dependent variable is the change in satisfaction with democracy between the pre-election and post-election measurements. The main predictor of interest is turnout. To take ceiling effects into account, we control for pre-election satisfaction. The result clearly corroborates 


\section{Figure 1}

\section{Predicted Probability to Vote and Satisfaction with Democracy}

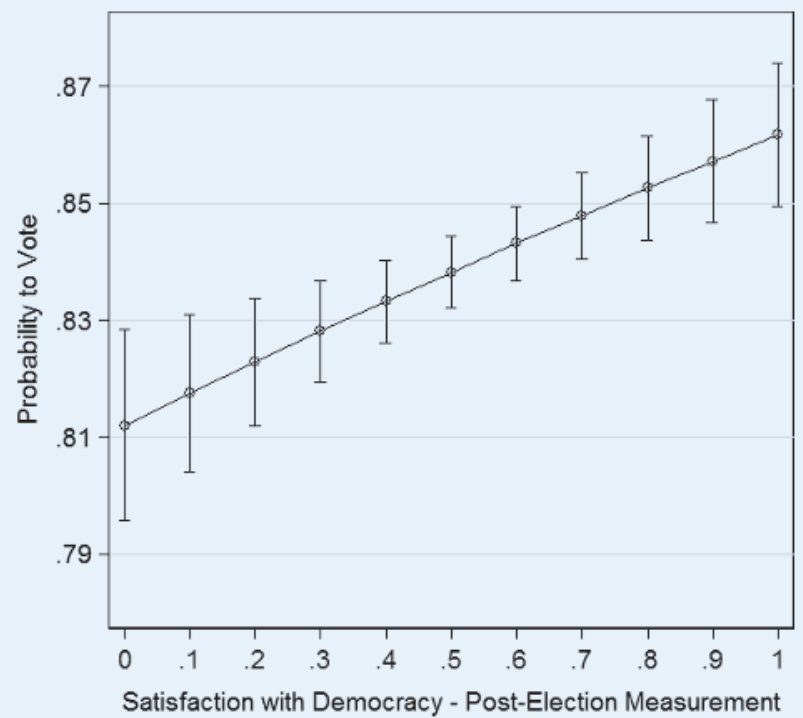

Note: The error bars indicate $95 \%$ confidence intervals.

hypothesis 2: voting increases satisfaction with democracy by 0.02 (o.2 on the $0-10$ scale) among voters when compared to abstainers (the reference category).
Table 2

\section{Pre-Post Change in Satisfaction with Democracy and Turnout}

B

\begin{tabular}{lc}
\hline Voted & $0.02^{* * *}(0.01)$ \\
\hline Pre-Election Satisfaction & $-0.43^{* * *}(0.01)$ \\
\hline Female & $-0.01(0.00)$ \\
\hline Age & $-0.00(0.00)$ \\
\hline Post-Secondary Education & $0.01^{* * *}(0.00)$ \\
\hline Interest in Politics & $0.04^{* * *}(0.01)$ \\
\hline Political Knowledge & $0.03^{* * *}(0.01)$ \\
\hline Feel Close to a Party & $0.01^{* *}(0.00)$ \\
\hline Election-Region Dummy Variables & Yes \\
\hline Constant & $0.23^{* * *}(0.01)$ \\
\hline $\mathrm{N}$ & 19076 \\
\hline $\mathrm{R}^{2}$ & 0.25 \\
\hline
\end{tabular}

Note: OLS Regression coefficients with robust standard errors in parentheses. ${ }^{*} p<0.05, * * 0<0.01,{ }^{* * *} p<0.001$

national and subnational elections in the remaining analyses. Figure 3 displays the effects of electoral systems. In line with hypothesis 4 , elections run under majoritarian rules increase satisfaction among voters twice as strongly (0.04) as elections in proportional systems (0.02). As in figure 2,

\section{There is no evidence that those who are less satisfied before the election vote less.}

To test hypotheses 3 and 4, we added election type and electoral system as predictors in the model presented in table 2. Each variable was also interacted with voting. We plot the effects of these variables in figures 2 and $3 .{ }^{6}$ We use average marginal effects, which express the predicted change in satisfaction with democracy for voters and abstainers in different institutional contexts.

In terms of election types (figure 2), national and subnational elections increase voters' satisfaction by approximately 0.03 while exerting no effect on abstainers. Conversely, supranational elections to the European Parliament depress satisfaction in the whole electorate by practically the same amount. This validates and even exceeds the expectations of hypothesis 3. It suggests that European Parliament elections expose the democratic imperfections of the European Union and, instead of boosting democratic satisfaction, they decrease it.

Given the peculiarity of supranational elections, we focus on

\section{Figure 2}

abstainers' level of satisfaction remains stable in both types of systems.

Finally, we examine the impact of perceptions of election outcomes. Figure 4 shows that, as predicted by hypothesis 5 , the effect is much stronger among election winners. Those who

\section{Predicted Pre-Post Change in Satisfaction with Democracy by Election Type}

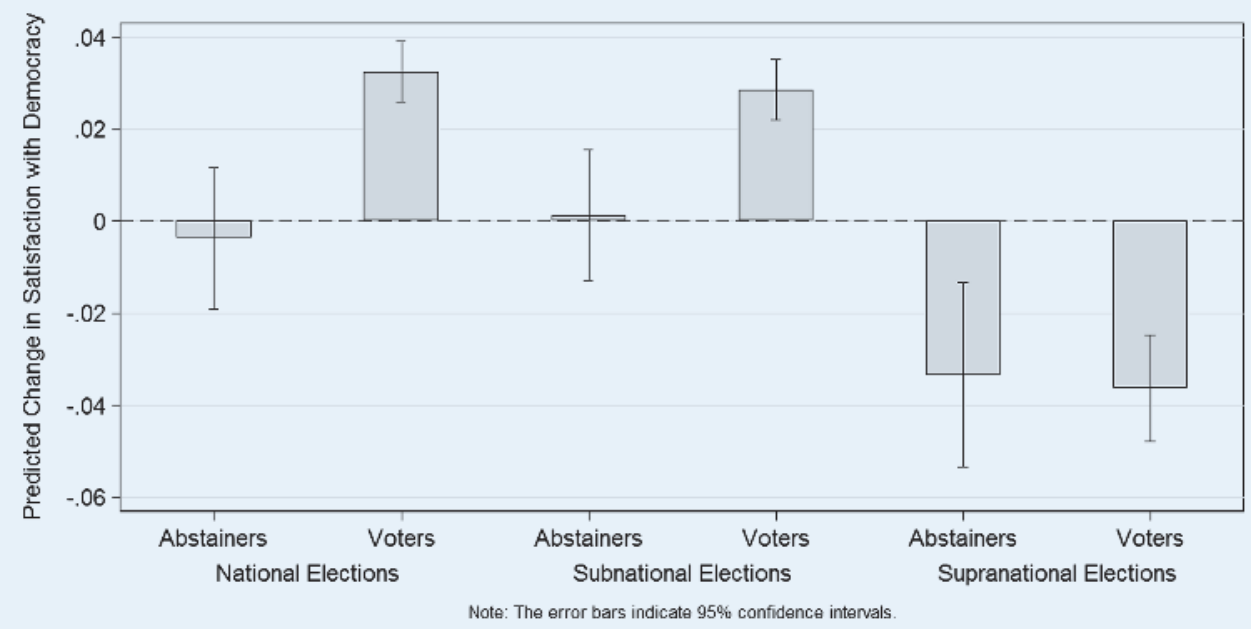



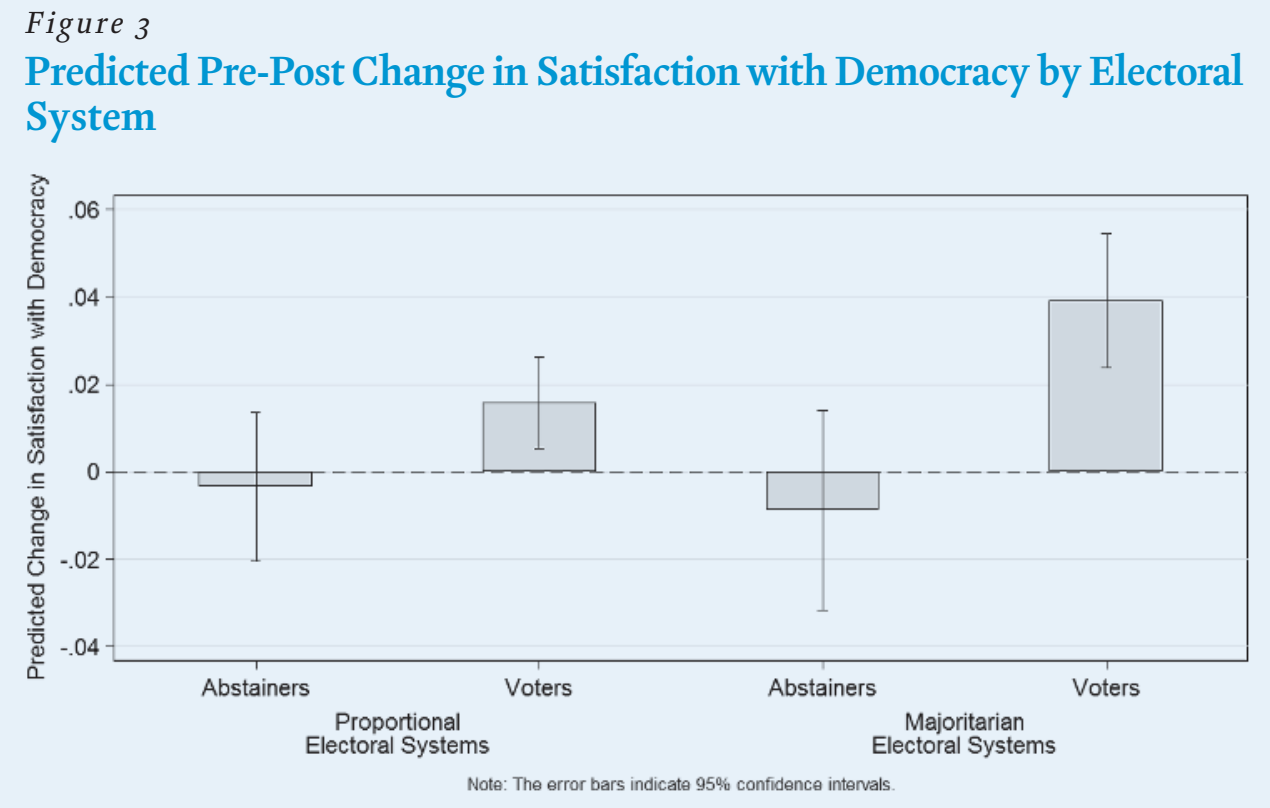

to the impact of satisfaction on voting but instead to the impact of voting on satisfaction. There is no evidence that those who are less satisfied before the election vote less.

Second, our analysis contributes to the broad literature on the role of elections in democracies. It provides robust support for the legitimizing effect of elections. We show that in national and subnational elections, especially those run under majoritarian rules, voting increases the satisfaction of all voters-even those who lost the election-and that it strongly boosts the satisfaction of those who believe they won the election. In that respect, the generalized boost in satisfaction with democracy resembles the honeymoon effect, which also affects both election winners and losers (Brody 1991). Future studies should investigate to what extent the two phenomena are related and whether the electiondriven boost in satisfaction with democracy is as temporary as the honeymoon.

There are certainly circumstances in which citizens can become less satisfied after an election. In this study, we found that supranational elections decrease satisfaction both among voters and abstainers. Similar negative effects can be expected in other contexts in which elections produce outcomes that are seen as distorted, illegitimate or ineffective, and it may affect especially those who voted for parties that fail to gain any representation (Blais, Morin-Chassé, and Singh 2015). For instance, satisfaction may decrease among those voters in the United States whose preferred presidential candidate loses the White House despite winning the popular vote, as did the Democratic candidate in 2000 and 2016 (Craig et al. 2006). More generally, future research should explore in greater detail how contextual factors such as disproportionality or party system fragmentation condition the effect of elections on citizens' satisfaction.

Third, our findings underline the pitfalls of using satisfaction with democracy measured in post-electoral surveys to predict voting behavior. These attitudes are likely to be affected by the election itself. The causal arrow may go in the other direction: from voting behavior to attitudes.

Finally, our results remind us that elections are a central democratic institution. In retrospect, it seems obvious that elections affect how citizens perceive the functioning of democratic regimes. This does not rule out the possibility that other factors such as political scandals may produce strong shifts in satisfaction with democracy (Kumlin and Esaiasson 2012). The bottom line, however, is that elections matter and that, most of the time, participating in an election makes citizens more satisfied with the way democracy works.

\section{SUPPLEMENTARY MATERIAL}

To view supplementary material for this article, please visit https://doi.org/10.1017/S1049096517002050 — 


\section{NOTES}

1. We follow the conventional terminology in political science literature and consider plurality systems as part of the majoritarian family of electoral systems.

2. British Columbia, Ontario, and Quebec in Canada; Ile de France and Provence in France; Lower Saxony in Germany; Catalonia and Madrid in Spain; Lucerne and Zürich in Switzerland.

3. The exact wording of the question was in both the pre-election and post-election surveys as follows: "On a scale from o to 10 where o means 'not satisfied at all" and 10 means 'very satisfied,' how satisfied are you with the way democracy works at the [election-related level of governance]?" Half of respondents were asked this question at the beginning of each survey and the other half at the end.

4. Respondents can say that their party won, lost, or that they do not know. The variable is available only for approximately two thirds of respondents in the pooled dataset.

5. The joint inclusion of the two measurements in the regression model is not problematic since, although they measure the same concept, they are only moderately correlated $(\mathrm{r}=0.63)$.

6. Full regression results are available in the online appendix.

\section{REFERENCES}

Aarts, Kees, and Jacques Thomassen. 2008. "Satisfaction with Democracy: Do Institutions Matter?” Electoral Studies 27 (1): 5-18.

Anderson, Christopher J., André Blais, Shaun Bowler, Todd Donovan, and Ola Listhaug. 2005. Losers' Consent: Elections and Democratic Legitimacy. Oxford: Oxford University Press.

Anderson, Christopher J., and Andrew J. LoTempio. 2002. "Winning, Losing and Political Trust in America." British Journal of Political Science 32 (2): 335-51.

Banducci, Susan A., and Jeffrey A. Karp. 2003. "How Elections Change the Way Citizens View the Political System: Campaigns, Media Effects and Electoral Outcomes in Comparative Perspective." British Journal of Political Science $33(3): 443-67$

Beaudonnet, Laurie, André Blais, Damien Bol, and Martial Foucault. 2014. "The Impact of Election Outcomes on Satisfaction with Democracy under a Two-Round System." French Politics 12 (1): 22-35.

Blais, André. 2007. “Turnout in Elections." In The Oxford Handbook of Political Behavior, eds. Hans-Dieter Klingemann and Russell J Dalton, 621-35. Oxford: Oxford University Press.

—. 2010. "Making Electoral Democracy Work." Electoral Studies 29 (1): 169-70.

Blais, André, and François Gélineau. 2007. "Winning, Losing and Satisfaction with Democracy." Political Studies 55 (2): 425-41.

Blais, André, Alexandre Morin-Chassé, and Shane P. Singh. 2015. "Election Outcomes, Legislative Representation, and Satisfaction with Democracy." Party Politics 23 (2): 85-95.

Brody, Richard. 1991. Assessing the President: The Media, Elite Opinion, and Public Support. Stanford, CA: Stanford University Press.

Campbell, Ross. 2015. "Winners, Losers and the Grand Coalition: Political Satisfaction in the Federal Republic of Germany." International Political Science Review 36 (2): 168-84

Clarke, Harold D., and Allan Kornberg. 1992. "Do National Elections Affect Perceptions of MP Responsiveness? A Note on the Canadian Case." Legislative Studies Quarterly 17 (2): 183-204.

Craig, Stephen C., Michael D. Martinez, Jason Gainous, and James G. Kane. 2006. "Winners, Losers, and Election Context: Voter Responses to the 2000 Presidential Election." Political Research Quarterly 59 (4): 579-92.

Dahl, Robert Alan. 1971. Polyarchy: Participation and Opposition. New Haven, CT: Yale University Press.

Ezrow, Lawrence, and Georgios Xezonakis. 2016. "Satisfaction with Democracy and Voter Turnout: A Temporal Perspective." Party Politics 22 (1): 3-14.

Flickinger, Richard S., and Donley T. Studlar. 2007. "One Europe, Many Electorates? Models of Turnout in European Parliament Elections After 2004." Comparative Political Studies 40 (4): 383-404.
Follesdal, Andreas, and Simon Hix. 2006. "Why There Is a Democratic Deficit in the EU: A Response to Majone and Moravcsik." Journal of Common Market Studies 44 (3): 533-62.

Ginsberg, Benjamin, and Robert Weissberg. 1978. "Elections and the Mobilization of Popular Support." American Journal of Political Science 22 (1): 31-55.

Grönlund, Kimmo, and Maija Setälä. 2007. "Political Trust, Satisfaction and Voter Turnout." Comparative European Politics 5 (4): 400-422.

Hadjar, Andreas, and Michael Beck. 2010. "Who Does Not Participate in Elections in Europe and Why Is This?" European Societies 12 (4): 521-42.

Henderson, Ailsa. 2008. "Satisfaction with Democracy: The Impact of Winning and Losing in Westminster Systems." Journal of Elections, Public Opinion and Parties 18 (1): $3-26$.

Huntington, Samuel P. 1991. The Third Wave: Democratization in the Late 20 th Century. Norman: University of Oklahoma Press.

Karp, Jeffrey A., and Caitlin Milazzo. 2015. "Democratic Scepticism and Political Participation in Europe." Journal of Elections, Public Opinion and Parties 25 (1): 97-110.

Kostadinova, Tatiana. 2003. "Voter Turnout Dynamics in post-Communist Europe." European Journal of Political Research 42 (6): 741-59.

Kumlin, Staffan, and Peter Esaiasson. 2012. "Scandal Fatigue? Scandal Elections and Satisfaction with Democracy in Western Europe, 1977-2007." British Journal of Political Science 42 (2): 263-82.

Linde, Jonas. 2012. "Why Feed the Hand That Bites You? Perceptions of Procedural Fairness and System Support in Post-Communist Democracies." European Journal of Political Research 51 (3): 410-34.

Linde, Jonas, and Joakim Ekman. 2003. "Satisfaction with Democracy: A Note on a Frequently Used Indicator in Comparative Politics." European Journal of Political Research 42 (3): 391-408.

Lipset, Seymour Martin. 1981. Political Man: The Social Bases of Politics. Baltimore, MD: Johns Hopkins University Press.

Nadeau, Richard, and André Blais. 1993. "Accepting the Election Outcome: The Effect of Participation on Losers' Consent." British Journal of Political Science $23(4): 553-63$.

Norris, Pippa. 1999. "Introduction: The Growth of Critical Citizens." In Critical Citizens: Global Support for Democratic Governance, ed. Norris, Pippa, 1-27. Oxford: Oxford University Press.

. 2011. Democratic Deficit: Critical Citizens Revisited. New York: Cambridge University Press.

Pacek, Alexander C, Grigore Pop-Eleches, and Joshua A. Tucker. 2009. "Disenchanted or Discerning: Voter Turnout in Post-Communist Countries." Journal of Politics 71 (2): 473-91.

Reif, Karlheinz, and Hermann Schmitt. 1980. "Nine Second-Order National Elections - a Conceptual Framework for the Analysis of European Election Results." European Journal of Political Research 8 (1): 3-44.

Singh, Shane, Ekrem Karakoç, and André Blais. 2012. "Differentiating Winners: How Elections Affect Satisfaction with Democracy." Electoral Studies 31 (1): 201-11.

Singh, Shane P. 2014. "Not All Election Winners Are Equal: Satisfaction with Democracy and the Nature of the Vote." European Journal of Political Research 53 (2): 308-27.

Singh, Shane P., and Judd R. Thornton. 2016. "Strange Bedfellows: Coalition Makeup and Perceptions of Democratic Performance among Electoral Winners." Electoral Studies 42: 114-25.

Stephenson, Laura; André Blais, Damien Bol, and Filip Kostelka. 2017. Making Electoral Democracy Work. V1. Harvard Dataverse. doi:10.7910/DVN/ RRoNNQ.

The Herald. 2003. "Does a Low Election Turnout Indicate Voters Are Disillusioned or Content?" The Herald, April 26. Factiva.

Tingsten, Herbert. (1937) 1963. Political Behavior: Studies in Election Statistics. Totowa, NJ: Bedminster Press.

Wilson, Francis G. 1936. "The Inactive Electorate and Social Revolution" The Southwestern Social Science Quarterly 16 (4): 73-84. 


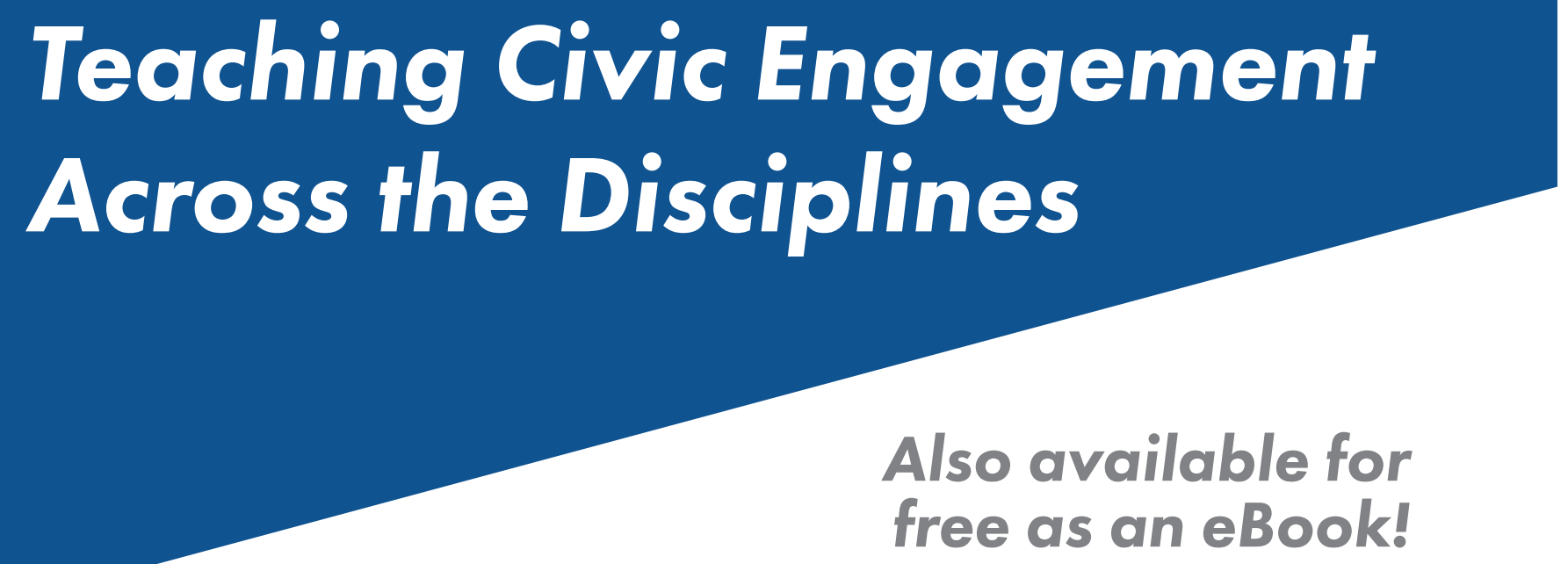

A new wave of civic instruction is moving through American education. As numerous national groups and institutions are joining this effort, political science is uniquely equipped to advance the teaching of civic engagement. The discipline should lead the movement for high quality civic education across the curriculum and across the disciplines.

To focus on this wave of civic engagement education, APSA is publishing the book Teaching Civic Engagement Across the Disciplines, edited by Elizabeth C. Matto, Rutgers University; Alison Rios Millett McCartney, Towson University; Elizabeth A. Bennion, Indiana University; and Dick Simpson, University of Illinois at Chicago.

The book redirects the focus from teaching better political science courses to teaching civic engagement across the disciplines. This movement involves university-wide coordinated civic engagement programs and action plans as well as a new nationwide action plan across high schools, community colleges, four-year colleges, and research universities to consolidate the gains that have been made and provide resources for the next leap forward. Building on the 2013 book Teaching Civic Engagement: From Student to Active Citizen, this book advances the conversation on civic engagement and provides critical scholarly insight into where to go next.

Available for purchase on Amazon! Visit www.apsanet.org/tce2.

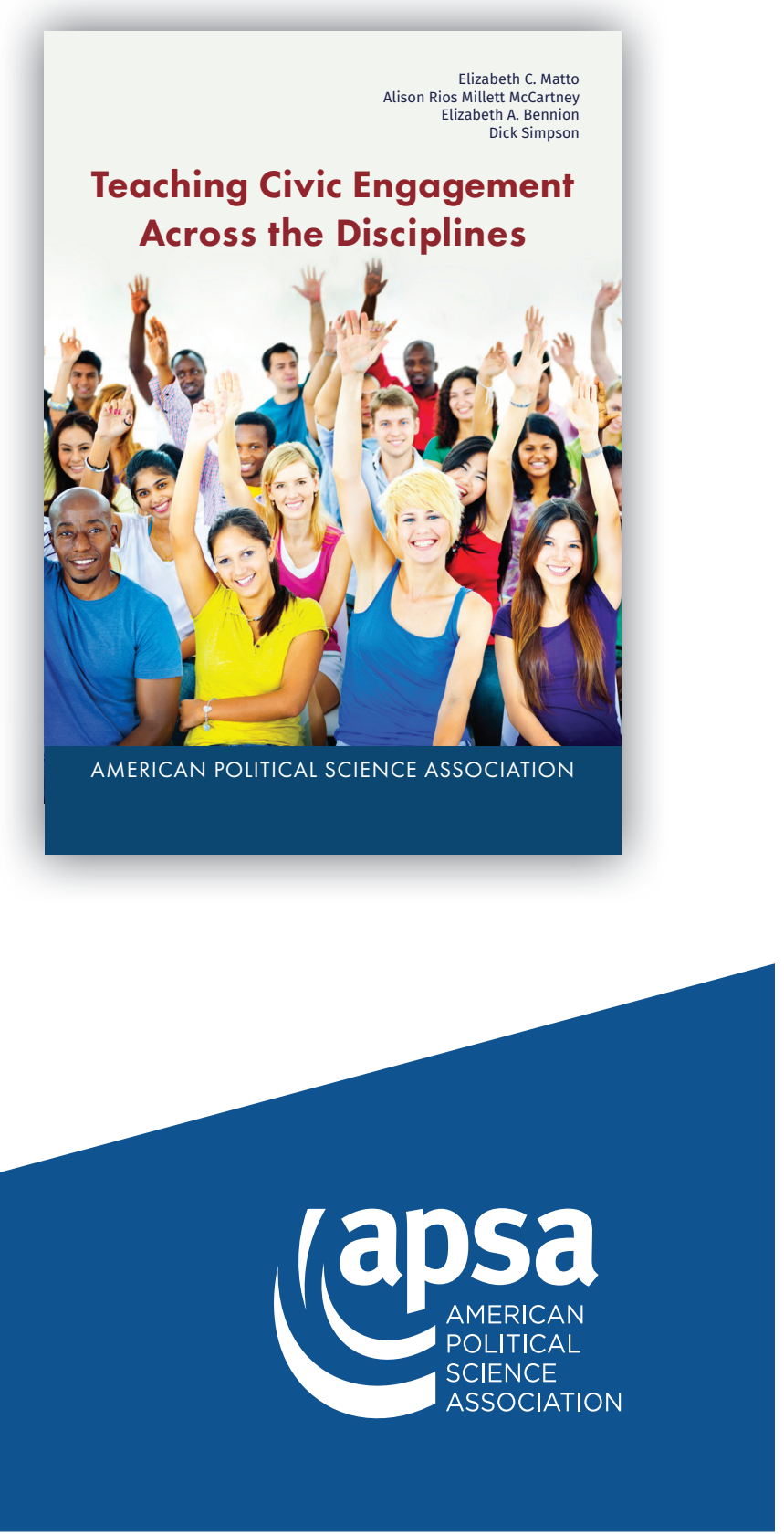

